\title{
Preview of Digital Literacy Ability of PAI Students at PTKIN Indonesia
}

\author{
Rahmawati, Fauzan, Lia Kurniawati \\ Postgraduate Program of the Faculty of Education \\ Syarif Hidayatullah State Islamic University (UIN) Jakarta
}

\begin{abstract}
The research work is based on digital literacy ability of PAI students at PTKIN Indonesia. The dynamics of the phenomenon and the complexity of the digital literacy as challenge to the 21st century education, a comprehensive study is needed. This study presents empirical data and shows the previously suggested differences in knowledge about students' digital literacy. Study focuses on the differences in capability the dimensions of information, communication, content-creation, social-emotional and problem solving. Study involved 1,200 respondents from six State Islamic University (UIN) in Indonesia. This research uses qualitative descriptive method to define, identify, analyze and interpret data relating to digital literacy ability the PAI students of PTKIN Indonesia. As a result, access to technology and online access PAI students of PTKIN Indonesia showed a difference quite clearly. While the difference in communication, social-emotional and problem-solving dimension is relatively close. PAI department of PTKIN Indonesia needs synergy to allocate an emphasis on the availability of infrastructure and digital literacy capabilities of students in a balanced manner. PAI departments in some PTKIN Indonesia campuses may still need to develop students' digital literacy ability, especially information and content-creation dimensions through optimizing ICT integration in learning.
\end{abstract}

\section{Introduction}

The reality of exponential growth of access to technology in various parts of the world, including Indonesia [2], echoes the need for appeal and reapplication of technology use [9]. This is supported by the current digital perception of the quality of use [1], which in this study we call digital literacy ability.

This study develops five important dimensions of PTKIN Indonesia's PAI students' digital literacy ability based on the concept of digital competence (DIGCOMP) for European consensus [10], which is combined with what some other experts suggest [3], [22], [23], [5], [14] and [19]. First, the information dimension: the ability to search, identify, evaluate and validate information on various digital media sources [22], [23], [14]; [19]; European Telecentre, 2014; [10]. Most experts agree that information

capability is very important when interacting with the Internet. For example, a large amount of information is unprofessional and unscientific in digital form rather than print [11]. Clearly, it requires the skills to evaluate and validate information [13]. Several studies have proven that young people and students grow in a technological environment, lack critical, lack of validation and evaluation skills [16], [6]. While the empirical findings of Graham and Takis Metaxas [24], reported students in addition to having difficulties in evaluating the results of information found on the Internet. They also cannot consistently distinguish between advertising and facts. The agreement shown by Bartlett and C. Miller [4], that native digital Internet users (12-18 years) are very confident, but they are not very competent. Too many digital originals do not apply checks to the information they access. This fact shows that not all native digital students are agile using information technology as assumed by Prensky [20], [21]. Second, the dimension of communication: the ability to communicate effectively with the digital environment, sharing, collaborating and interacting online makes it possible to participate in network communities and increase academic capacity [10]. The availability of physical access such as computers and Internet networks is not fully used by students to share information, communicate and collaborate online which allows for increased academic capacity. Margaryan and Littlejohn [25], explore the possibility of using information technology to support the learning and socialization process among students is still very limited. This is supported by DiMaggio and E. Hargittai [12], each individual and group have the goal of using different technologies. Third, the dimension of content creation, the ability to create and produce content that is different from before, integrates previous knowledge into the resulting content, implements intellectual property rights and licenses [5], [10]. Creativity to produce innovative new works and awareness to apply licenses are two things that are equally important for students. Disclosure of digital age information allows students to creatively produce new works that are different from before. At the same time, the ease of getting information online opens opportunities for students to take ideas of the work of others without writing the source. Fourth, the social-emotional dimension: the ability to be responsible for 
communicating, socializing online, avoiding and identifying various risks online, including the protection for privacy data [14], [10], [19]. Empirical findings of Buckingham [7], [26], [27], claiming intimacy and closeness of young people with technology do not always have the ability to use technology safely. At the same time, the ability to avoid and identify online risks and privacy data protection is no more important than the ability to be responsible when surfing the Internet. Fifth, the dimension of problem solving: the ability to overcome technical barriers when operating a computer and using digital means being creative to achieve certain goals [3], [10]. Computer operational technical capabilities is basic capabilities that can be developed by users to benefit from various online information sources, build communication and expand networks, and generate critical knowledge. Research at one of PTKIN Indonesia's campuses, reports that some PAI department students has not been involved in blogging. Even some of them have not been able to operate computers properly [15]. The empirical findings of Fuaidah [15] support the claims to other researchers (such as Caruso et al. [8]), that the proportion of student involvement in making the Web, reading Blogs and Wikis is quite low. This fact encourages the need for PAI departments / faculties at the Indonesian State Islamic University (PTKIN) to examine and ensure digital literacy ability in the student environment. The PAI Department has a strategic role to improve digital literacy ability to the PTKIN Indonesia student environment. The PAI Department is one of several departments that are quite popular with the public. Based on the report, the PAI administration department in six Indonesian PTKIN institutions noted that the number of active PAI students in the 2017/2018 academic year is not more than 5000 people that are most claimed to have accessed the internet. While the Indonesian PTKIN institution until December 2017 amounted to 57 institutions. The context of this study is to present empirical data on PAI students' digital literacy abilities in six Indonesian PTKIN institutions. Specifically, the study's digital literacy abilities cover five dimensions. First, the information dimension, namely the ability to explore, identify, and evaluate information about PAI material from various online sources. Second, the dimension of communication, refers to the ability to discuss PAI material in online groups, publish scientific papers on PAI in online journals, share PAI material through online resources, such as social media accounts, Web, Blogs and / or Wikis, create and activate groups online to expand the network to enable the development of insights on PAI material. Third, the content-creation dimension emphasizes the ability to make scientific work on PAI that is different from the previous author, internalizes previous experience in the PAI content produced, and implements intellectual property right and licenses from various sources of information they get on the Internet. Fourth, the social-emotional dimension, which is the ability to protect privacy data, carefully write and comment on online groups, and carefully share PAI content. Fifth, the dimensions of problem solving, referring to the ability to overcome the possibility of technical problems, and using technology creatively to help solve the conceptual problems of PAI material.

\section{Study Approach}

This study uses a qualitative descriptive approach located in the PAI department of six Indonesian PTKIN institutions, namely Syarif Hidayatullah State Islamic University Jakarta, Maulana Malik Ibrahim State Islamic University, UIN Sunan Kalijaga Yogyakarta, UIN Sunan Gunung Djati Bandung, Sunan Ampel State Islamic University Surabaya and Ar-Raniry State Islamic University Banda Aceh. Six PAI departments from PTKIN Indonesia institutions assigned to the research location have been accredited A (https://banpt.or.id/dirktori/prodi/pencarian_prodi), and are in two regions with the highest internet penetration rates in Indonesia [2].

This study involved 1,200 respondents aged 1724 years. Questionnaires were developed from previous studies [28]. 1550 questionnaires covering $10 \%$ are processed online (web-based surveys), and $90 \%$ are distributed in print media. Only $77.4 \%$ of questionnaires were complete and considered feasible for analysis. While $1.7 \%$ did not write the names of respondents and universities. About $10.3 \%$ of the questionnaires in the respondents' answers were incomplete and $10.6 \%$ of the questionnaires were not returned. The demographic profile of respondents can be seen in the Table 1 below.

\section{Findings}

\subsection{Students Digital Literacy Ability}

The study conducted found that although most PAI students tend to agree to use cellphones and the Web to find information. However, some of them do not apply checks on the content and sources of information they get online. Some report reluctant to read thoroughly the information they get on the Internet. The average percentage of students' digital literacy ability dimensions PTKIN PAI information can be seen on Graph 1. Graph 1 shows that there are around $87 \%$ of PAI students, PTKIN Indonesia uses cellphones to download or upload digital audio files about PAI material. 
Table 1. The DemoGraphic Profile of Respondents

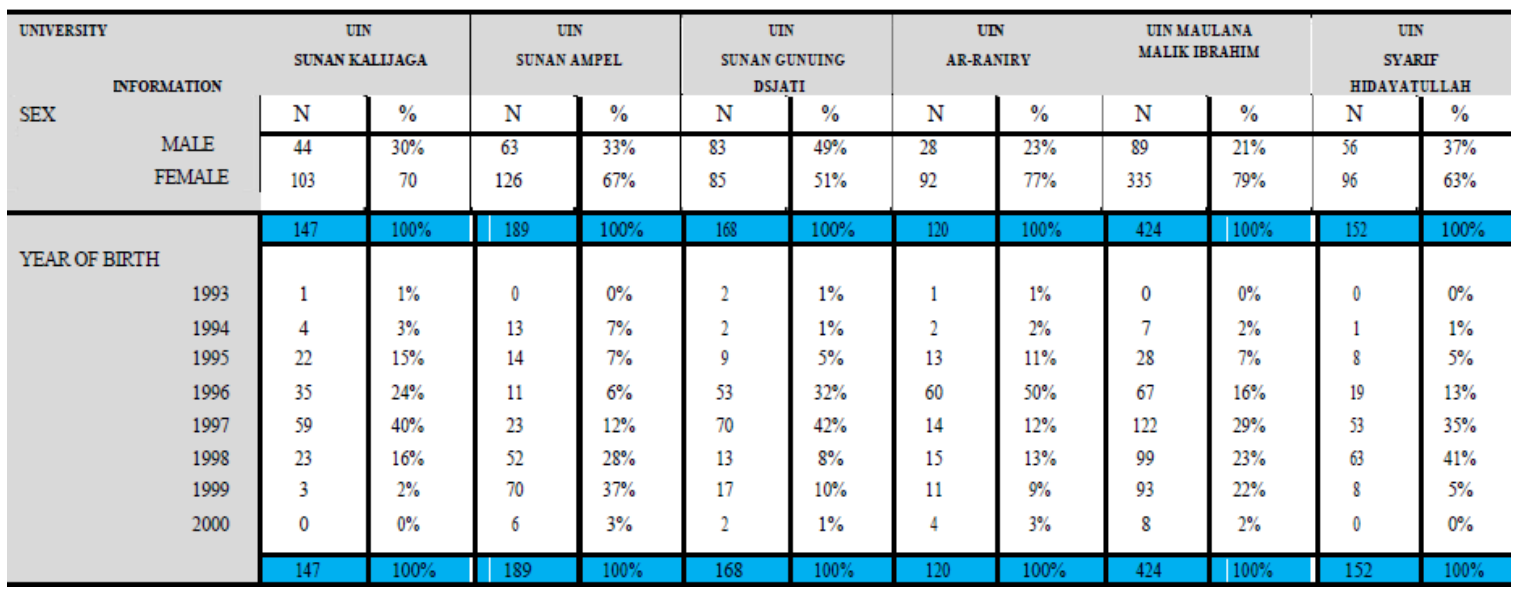

Graph 1. Precentage of Students Digital Literacy Ability Department PAI PTKIN Indonesia in Dimension Information

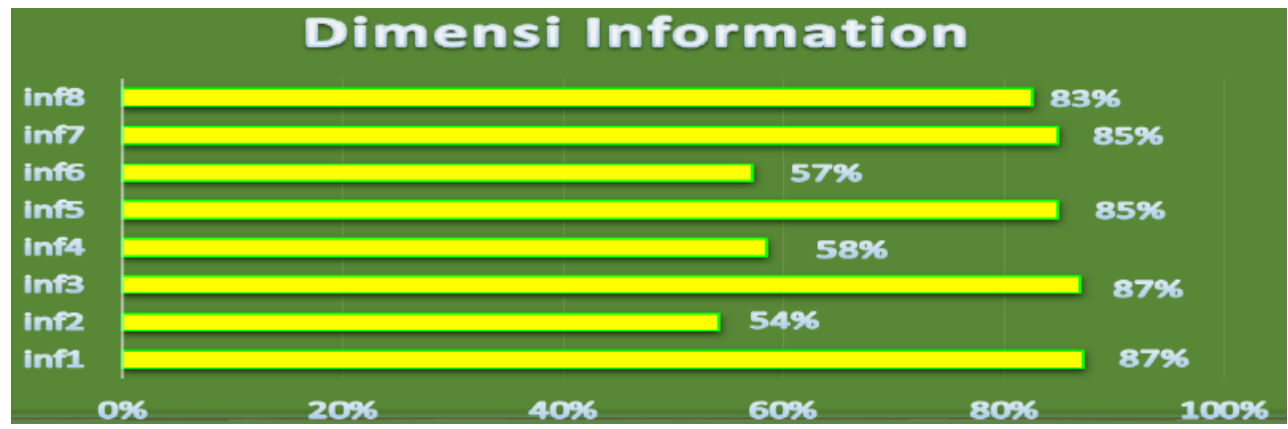

Note.

Inf: Information

Inf1: Use mobile phone to download or upload digital audio files about PAI materials (Qur'an Hadist, Aqidah Ahlak, Fiqh dan SKI)

Inf2: It is difficult to know when the last information about PAI material Qur'an Hadist, Aqidah Ahlak, Fiqh and SKI) which is on the Website update.

Inf3: Use the Web to find information about PAI materials (Qur'an Hadist, Aqidah Ahlak,Fiqh and SKI)

Inf4: It is difficult to identify important and insignificant information about PAI materials (Qur'an Hadist, Aqidah Ahlak, Fiqh and SKI) that I get on the Internet

Inf5: Use the Web to download and share document files (eg Word and PDF) on PAI materials (Qur'an Hadist, Aqidah Ahlak, Fiqh and SKI)

Inf6: It is difficult to analyze sources of information about PAI materials (Qur'an Hadist, Aqidah Ahlak, Fiqh and SKI) obtained on the Internet

Inf7: Use mobile to find information about PAI materials (Qur'an Hadist, Aqidah Ahlak, Fiqh and SKI)on the Internet

Inf8: Using the Web to access the University's portal or PAI learning management system

No less than $54 \%$ of them find it difficult to know when the latest information about PAI material on the Website has been updated. While $87 \%$ of PAI students use the Web to find information about PAI material. About $58 \%$ found it difficult to identify important and unimportant information about PAI material obtained on the Internet. $85 \%$ of PAI students use the Web to download and share document files (e.g.: Word and PDF) on PAI material. While $57 \%$ of them found it difficult to analyze information sources about PAI material obtained on the Internet. $85 \%$ of PAI students use 
cellphones to find information about PAI material. And, $83 \%$ of them use the Web to access the University portal or PAI learning management system.

3.1. Digital Literacy Ability Students Department PAI PTKIN Indonesia in Dimension Communication Digital literacy ability in the communication dimension of Indonesian PTKIN PAI students look quite smooth. The results of the interviews show that only a small proportion of students used the Web for Skype calls. Even some of them don't know about Skype. Rofik "Aku belum pernah nyoba aplikasi Skype untuk kontak teman-teman." "I have never tried the Skype application to contact friends." While Samsul reported "Saya tahu Skype ka, tapi jarang menggunakan karena teman-teman saya jarang yang punya akun Skype." "I know Skype, but I rarely use it because my friends rarely have Skype accounts." At the same time, some PAI students have never published scientific papers on the PAI Web course. Only a small number of they have uploaded the results of the course or scientific work on PAI on the Website. Zamzam "Saya bikin Website beberapa tahun yang lalu, tapi sebagian besar karya saya yang diterbitkan di Website tidak berhubungan dengan PAI, ada sih tapi hanya satu dua." "I created a Website a few years ago, but most of the works published on the Website is not related to PAI, there are only one or two." Agus "Saya belum pernah menerbitkan karya ilmiah PAI di Website ka." "I have never published PAI scientific work on the website." Nisa "Ada Website, tapi hanya tugas-tugas mata kuliah yang aku upload ka. Kalau karya besar, seperti penelitian belum pernah ka." "There is a Website, but only the course assignments I uploaded are great. If it works great, like the research has never been done before." While some other students reported not having a website. Digital literacy ability of the Indonesian PTKIN PAI students' communication dimensions are shown in Graph 2.

Graph 2. Percentage of Students Digital Literacy Ability in Communication Dimension

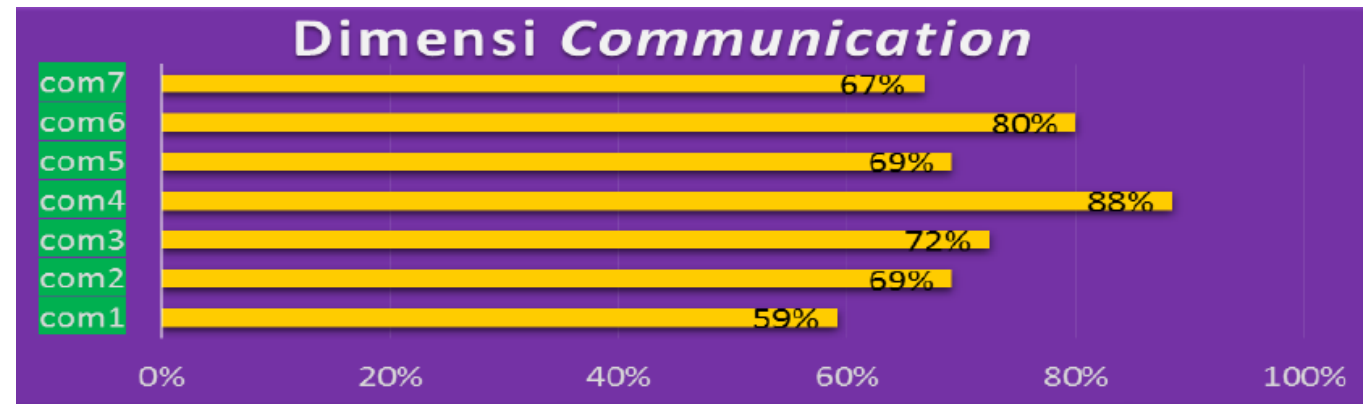

Note.

Com: Communication

Com1: It is difficult to use the Web to make phone calls (eg Skype) to friends or lecturers of PAI

Com2: Use mobile to receive or send E-mail to friends or lecturers of PAI

Com3: It is difficult to use the Web to publish scientific papers on PAI materials (Qur'an Hadist, Aqidah Ahlak, Fiqh and SKI)

Com4: Use mobile to call or receive calls from friends or lecturers of PAI

Com5: Reluctant to use social networking (eg Facebook, Instagram, Twitter, LinkedIn and Line) to discuss PAI material

Com6: Using social networks (eg Facebook, Instagram, Twitter, LinkedIn and Line) to share material content PAI (Qur'an Hadist, Aqidah Ahlak, Fiqh and SKI

Com7: Reluctant to use the Web to read and comment on other people's Blog about PAI materials (Qur'an Hadist, Aqidah Ahlak, Fiqh and SKI)

Graph 2 shows that around 59\% of students find it difficult to use the Web to make phone calls (eg Skype) to PAI friends or lecturers. No less than $69 \%$ of them use cellphones to receive or send e-mail to friends or PAI lecturers. While $72 \%$ of PAI students have difficulty using the Web to publish scientific papers on PAI material. About $88 \%$ of them use cellphones to call or receive calls from friends or
PAI lecturers and $69 \%$ are reluctant to use social networks to discuss PAI material. About $80 \%$ of PTKIN Indonesia's Islamic Studies (PAI) students use social networks to share PAI material content. And, $67 \%$ of them are reluctant to use the Web to read and comment on other people's blogs about PAI material. 
Graph 3. Precentage of Student Digital Literacy Ability in Content-Creation Dimension

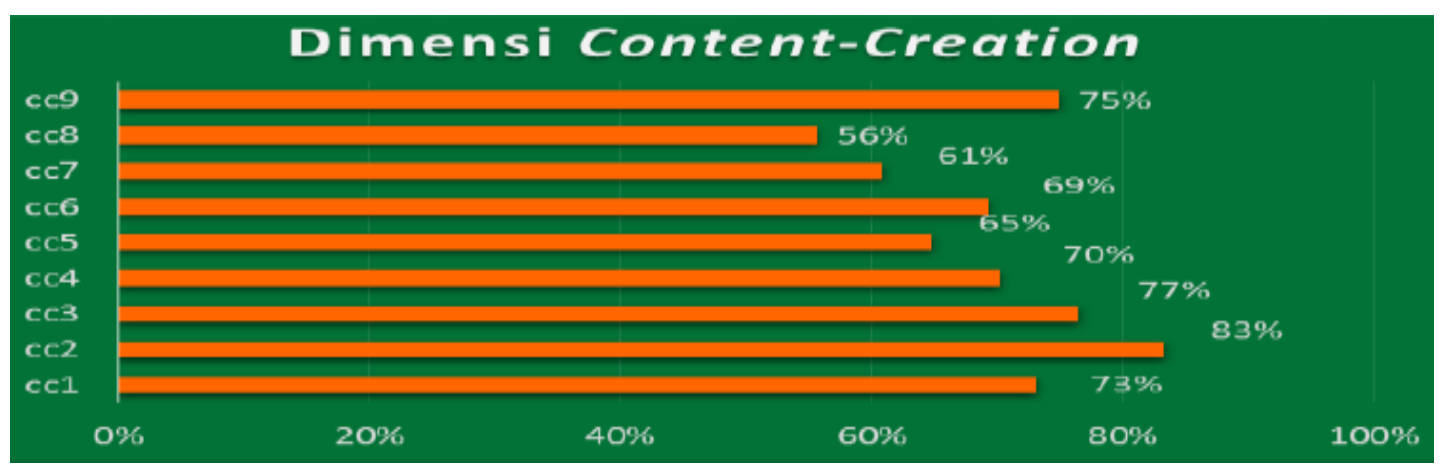

Note.

CC: Content Creation

CC1: Difficult to use digital (eg certain applications) to create unique drawings or posters about the movies of the PAI (Qur'an Hadist, Aqidah Ahlak,Fiqh and SKI)

CC2: Can use computer to write Word document or PDF about PAI material (Qur'an Hadist, Aqidah Ahlak, Fiqh dan SKI)

CC3: Use computer to create PowerPoint presentations on PAI materials (Qur'an Hadist, Aqidah Ahlak, Fiqh dan SKI)

CC4: Reluctant to use the Web to contribute PAI materials (Qur'an Hadist, Aqidah Ahlak, Fiqh dan SKI) at Wiki

CC5: Write articles in Blog about PAI materials (Qur'an Hadist, Aqidah Ahlak, Fiqh dan SKI)

CC6: Can combine previous experience into articles written on Blog about PAI materials (Qur'an Hadist, Aqidah Ahlak, Fiqh dan SKI)

CC7: Feel difficult using digital means (eg certain apps) to make short films themed PAI materials (Qur'an Hadist, Aqidah Ahlak, Fiqh dan SKI)

CC8: It is difficult to create a Vlogging (Video Blog) on Youtube about PAI materials (Qur'an Hadist, Aqidah Ahlak, Fiqh dan SKI)

CC9: Reluctant to include online information or reference sources into papers on PAI materials (Qur'an Hadist, Aqidah Ahlak, Fiqh dan SKI)

\subsection{Student Digital Literacy Dimension Content-Creation}

This study shows only a small part of the Indonesian PAI PTKIN students that wrote on Blogs about PAI material. Not having a blog is the most common reason. While some students have Blogs. They rarely write PAI material content. Ivan "Aku belum pengalaman menulis di Blog mba. Karena belum sempat buat blog." "I have never written on a blog, because I have never written a Blog." Irfan "Meskipun saya punya Blog, tapi tapi saya jarang menulis tentang mata kuliah PAI teh. Saya lebih fokuskan untuk bisnis." "Even though I have a Blog, but I rarely write about PAI courses. I focus more on business." The average percentage of digital literacy ability of the dimension of creating student content from PTKIN Indonesia PAI can be seen on Graph 3.

Graph 3 shows that around $73 \%$ of PAI students reported that they had difficulty using digital facilities (for example certain applications) to create unique drawings or posters about the motivation of PAI-themed material. $83 \%$ of them can use a computer to write Word or PDF documents about PAI material. While $77 \%$ of PAI students use computers to make PowerPoint presentations on PAI material and $70 \%$ are reluctant to use the Web to contribute PAI material on the Wiki. About $65 \%$ of students write blog articles about PAI material and $69 \%$ of them can incorporate previous experience into articles written on blogs about PAI material. No less than $61 \%$ of PTKIN Indonesia's PAI students find it difficult to use digital tools (for example certain applications) to make short films with PAI material and $56 \%$ find it difficult to make Vlogging about PAI material. $75 \%$ of PAI students were reluctant to enter information sources or online references into papers on PAI material. 


\subsection{Student Digital Literacy Ability in Social-Emotional Dimension}

The Researchers observed the tendency of PAI student at PTKIN Indonesia to use social media to establish quite small connections. Only a small percentage of them have accounts on social media that are used to connect with friends and people from the same profession, from local, national to international. The reason is to get a lot of information and share experiences. Dedy "Saya punya beberapa akun di media social ka, dan temanteman saya ada yang dari luar kok. Alhamdulillah saya mendapat banyak pengetahuan dan pengalaman ketika berinteraksi dengan mereka. Tapi tantangannya di bahasa ka." "I have several accounts on social media, and my friends are from outside. Thank God I got a lot of knowledge and experience using them. But the challenge is in language." Adri "Kalau akun di media social kadang saya pakai untuk sosialisasi dan berbagi informasi ka. Teman saya sedang, ga banyak ga sedikit dan sebagian besar mereka dari Indonesia. Belum ada yang dari luar ka." "If I use social media accounts for socialization and sharing information. My friends are currently, not many are few and most of them are from Indonesia. No one from outside." While most PAI students, PTKIN Indonesia has not optimized the use of social networks as a tool to build connections that support their academic. Digital literacy ability of the socialemotional dimensions of Indonesian PTKIN PAI students are shown in Graph 4.

Graph 4. Percentage Student of Digital Literacy Ability in Social-Emotional Dimension

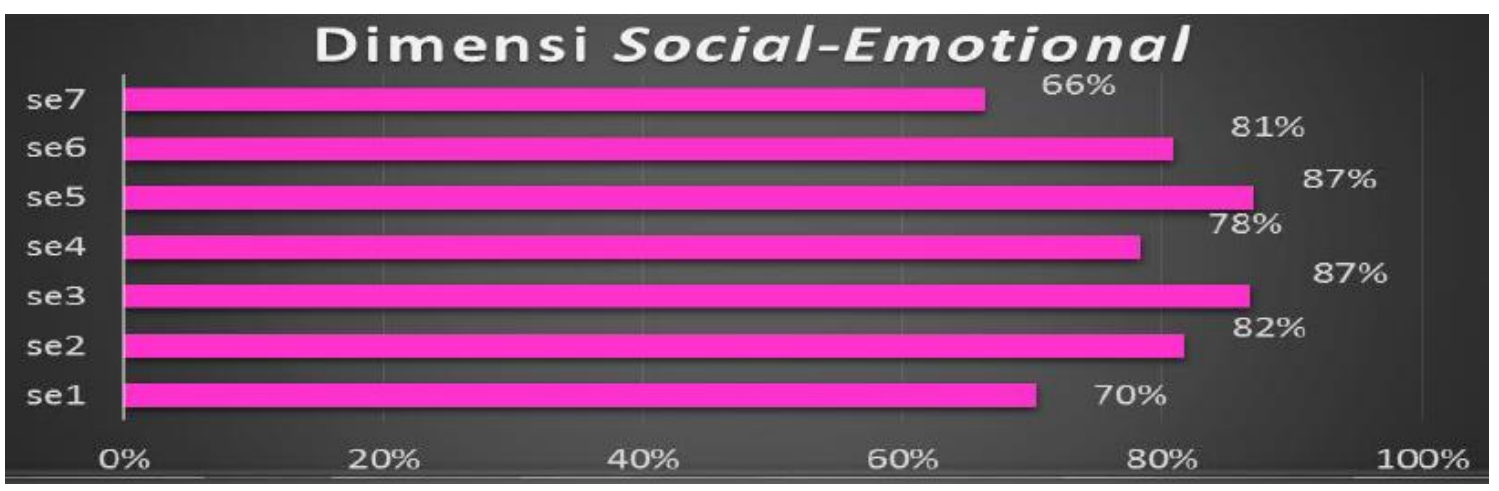

Note:

SE: Social-Emotional

SE1: Reluctant to use social networks (eg Facebook, Instagram, Twitter, LinkedIn and Line) to build connections at National and International levels that support academic tasks

SE2: Read carefully before commenting on the material content of PAI (Qur'an Hadist, Aqidah Ahlak, Fiqh dan SKI) distributed through social networks (eg Facebook, Instagram, Twitter, LinkedIn and Line)

SE 3: Respecting differences of opinion when discussing the material of PAI (Qur'an Hadist, Aqidah Ahlak, Fiqh dan SKI) on social networks (eg Facebook, Instagram, Twitter, LinkedIn And Line)

SE4: Ignoring other people's feelings in writing comments on social networks (eg Facebook, Instagram, Twitter, LinkedIn and Line)

SE5: Respect the privacy of others while communicating online on social networks (eg Facebook, Instagram, Twitter, LinkedIn and Line)

SE6: Ignoring legal risks communicating online on social networks (eg Facebook, Instagram, Twitter, LinkedIn and Line)

SE7: Comment and share content on social networks (eg Facebook, Instagram, Twitter, LinkedIn and Line) when emotions

Graph 4 shows that around $70 \%$ of PAI students are reluctant to use social networks to establish connections to National and International levels that support academic assignments. While $82 \%$ of PAI students read manually before commenting on the content of PAI material distributed among social networks and $87 \%$ of them appreciate differences of opinion when discussing PAI material on social networks. At the same time, $78 \%$ of students like the feelings of others in writing comments on social networks. $87 \%$ of them respect the privacy of others when communicating online with social networks. $81 \%$ tend to ignore the legal risks of online social networks. And, no more than $66 \%$ of PAI students 
Graph 5. Precentage Digital Literacy Ability Student Department PAI PTKIN Indonesia in Dimension Problem Solving

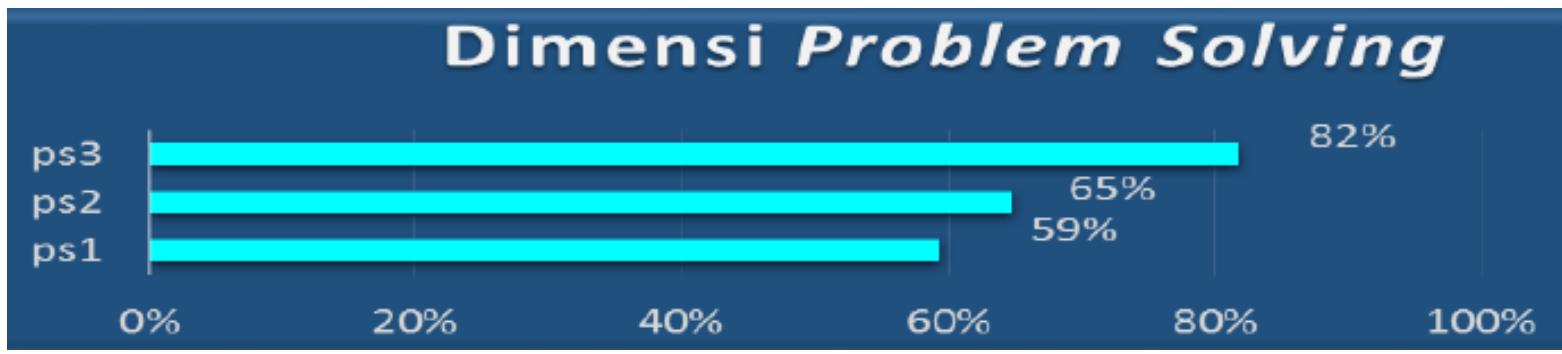

Note:

PS: $\quad$ Problem Solving

PS1: Feel difficult to overcome technical obstacles while doing material tasks PAI (Qur'an Hadist, Aqidah Ahlak, Fiqh dan SKI)

PS2: Take courses (additional lessons) to improve skills in accessing online information about PAI materials (Qur'an Hadist, Aqidah Ahlak, Fiqh dan SKI)

PS3: Using digital means (eg certain applications) to help with the tasks on PAI materials (Qur'an Hadist, Aqidah Ahlak, Fiqh dan SKI)

comment and about social networking content when emotion.

\subsection{Student Digital Literacy Ability in Problem Solving Dimension}

Our findings are based on the technical agility of using digital has been owned by most Indonesian PTKIN PAI students. And, most of them reported using digital tools to help with assignments to PAI courses. This data proves that ICTs are very helpful for their learning. The average percentage of digital literacy dimensions of students solving PTKIN Indonesia's PAI problems can be seen on Graph 5.

Graph 5 shows that no more than $59 \%$ of PTKIN PAI students in Indonesia have difficulty overcoming technical obstacles when doing PAI material assignments and $65 \%$ of them claim to take courses (additional lessons) to improve skills in accessing online information about PAI material. While around $82 \%$ of PAI students use digital means (for example certain applications) to help with assignments to PAI material. We also noted the summary of empirical findings of digital literacy ability between each of the sixth dimensions of UIN Indonesia, as shown in Graph 6.

Graph 6 shows the percentage of digital literacy ability for the information dimension PAI students of UIN Gunung Djati is 76\%. PAI students of UIN Sunan Ampel and UIN Ar-Raniry have a percentage of $74 \%$. Whilye students of UIN Sunan Kalijaga and UIN Maulana Malik Ibrahim with a percentage of $65 \%$. For the communication dimension of digital literacy ability, PAI students of UIN Sunan Ampel and UIN Sunan Gunung Djati have the same high publication (73\%) compared to students in four other
State Islamic University (UIN). While PAI students of UIN Syarif Hidayatullah and UIN Ar-Raniry showed the same low percentage $(71 \%)$ of the four other State Islamic University (UIN). While for the content creation dimensions the PAI students of UIN Sunan Kalijaga are at the highest number (71\%). Follow by PAI students from Sunan Ampel, UIN Sunan Gunung Djati and UIN Maulana Malik Ibrahim with the acquisition of $70 \%$. And, the lowest number $(68 \%)$ was achieved by PAI students of UIN Ar-Raniry and UIN Syarif Hidayatullah. The percentage of the social-emotional dimensions of PAI students of UIN Sunan Kalijaga and UIN Sunan Ampel is at the highest position $(80 \%)$ compared to the same students in the four other State Islamic University (UIN). While PAI students from UIN ArRaniry and UIN Syarif Hidayatullah have the same number of low (77\%) compared to the four other State Islamic University (UIN) in Indonesia. In the dimension of problem solving, PAI students of UIN Sunan Gunung Djati and UIN Ar-Raniry are the highest $(70 \%)$ compared to PAI students in the four other State Islamic University (UIN). While PAI students of UIN Sunan Kalijaga, UIN Sunan Ampel, UIN Maulana Malik Ibrahim and UIN Syarif Hidayatullah have the same low percentage $(68 \%)$ of the two other State Islamic University (UIN) in Indonesia.

\section{Discussion}

The evidence from our research shows that several dimensions of digital literacy ability PAI students of PTKIN in Indonesia is still quite low. 
Graph 6. Percentage of Digital Literacy Ability Between Each of the Sixth Dimensions of UIN Indonesia

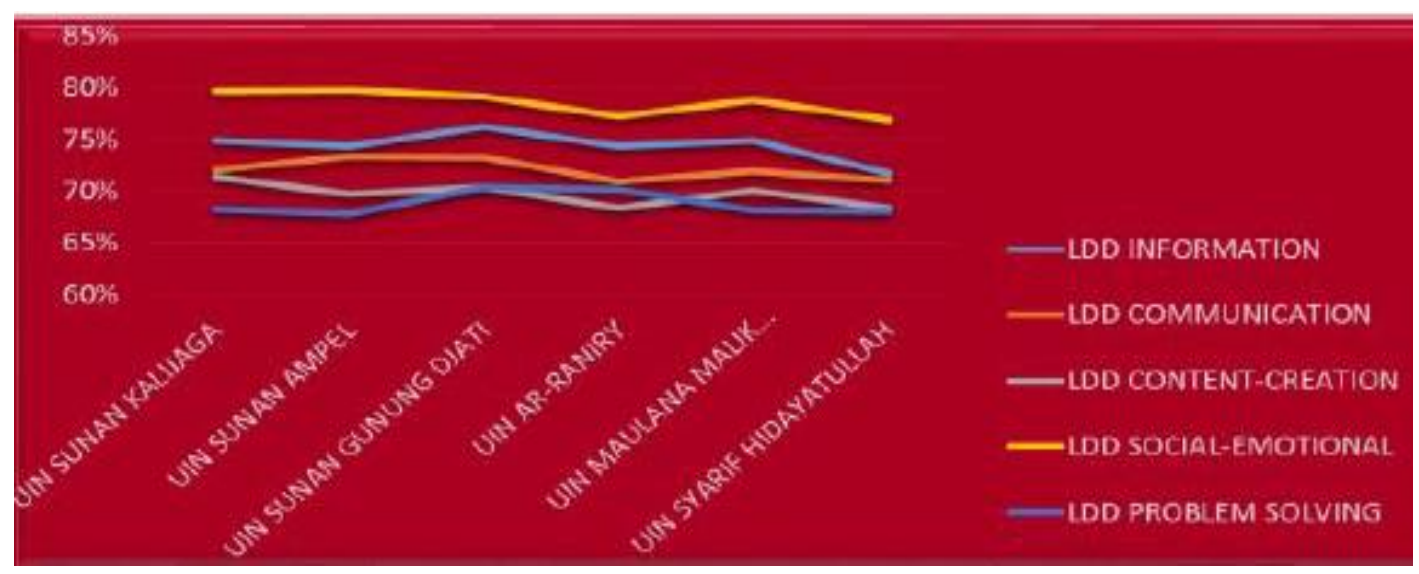

Note. LDD: Digital Literacy Dimension

The researcher records all findings in the field carefully without intending to correct them. Researchers found an interesting thing related to the digital literacy ability PAI students of PTKIN Indonesian PTKIN. The availability of ICT facilities for learning PAI in several Indonesian Islamic State University (UIN) is not directly proportional to their digital literacy ability. This shows the availability of physical access is not the most important predictor that affects the level of a person's digital literacy. The argument that supports this finding is that Internet uses does not have a significant impact on students' digital competencies [17]. Empirical data in this study shows that there are still many PAI students that are not skilled at using the Internet. Evidently, around $59 \%$ of PAI students find it difficult to use the Web to make phone calls (eg Skype) and $72 \%$ find it difficult to use the Web to publish scientific papers. While $56 \%$ of them found it difficult to make Vlogging. The findings of this study support the argument with Spengler [18], that although the millennium generation is skilled at using ICT, it does not always have the ability to apply correctly.

\section{Conclusion}

The researchers noted that around 54\% PAI students of PTKIN Indonesia agreed that it was difficult to know when the latest information on the Website was updated and not less than $58 \%$ found it difficult to identify important and unimportant information obtained on the Internet. While $57 \%$ of them find it difficult to analyze sources of information obtained on the Internet. The results of this study corroborate the claim that youth familiarity with ICT does not mean they are critical and have content validation and information evaluation skills [6], [16].
At the same time, this research contradicts Prensky's argument about digital native students that have the agility of using technology over generations of digital immigrants [20], [21]. Researchers have not found strong evidence of what Prensky thinks about digital native students. PAI students of some PTKIN Indonesian, may be agile in using technology, but this does not apply to all original digital PAI students, such as Prensky [20], [21]. Empirical data shows that PAI students on several PTKIN Indonesia campuses supported by access to technology and online access still have weaknesses for several dimensions which are important predictors of digital literacy ability, as reviewed by this study. This fact provides important information to carefully examine and define digital natives based on age.

\section{Acknowledgements}

Thank you for the Postgraduate Program of the Faculty of Education Syarif Hidayatullah State Islamic University (UIN) Jakarta and the Directorate of State Islamic Higher Education (PTKIN) Ministry of Religion of the Republic of Indonesia that has supported.

\section{References}

[1] Vincze, A., (2015). Digital Gaps in School? Exploring the Digital Native Debate. Belvedere Meridionale Volume 27, No. 1, pp. 116-125.

[2] APJII, (2016). Infografis Penetrasi and Perilaku Pengguna Internet Indonesia. Survey, Polling Indonesia.

[3] Ba, H., Tally, W., and Tsikalas, K., (2002). Investigating Children"s Emerging Digital Literacies. 
Journal of Technology, Learning, and Assessment, Volume 1, No. 4, pp. 1-49.

[4] Bartlett, J. and Miller, C., (2011). Truth, Lies and the Internet a Report Into Young People's Digital Fluency. DEMOS. Third Floor Magdalen House 136 Tooley Street London SE12TU.

[5] Belshaw, D. A. J., (2011). What is 'Digital Literacy'? Ed.D Thesis. Available in http://neverendingthesis.com/ doug-belshaw-edd-thesis final.pdf. (Accessed April 27, 2017).

[6] Bennett, S. J., Maton, K. A. \& Kervin, L. K. (2008). The 'digital natives' debate: a critical review of the evidence. British Journal of Educational Technology, 39 (5), 775-786.

[7] Buckingham, D., (2005). Constructing the Media Competent Child: Media Literacy and Regulatory Policy in the UK. Medien Padagogik.

[8] Caruso, J. B., Fellow and Kvavik, R. B., (2005). ECAR Study of Students and Information Technology: Convinence, Connection, Control, and Learning. Educause Center For Applied Research, pp. 1-4.

[9] Cheryl, L., (2002). enGauge 21st Century Skills: Digital Literacies for a Digital Age. Office of Educational Research and Improvement (ED), Washington, DC. pp. 132. Full Text Provided by ERIC.

[10] Department of eLearning. (2015). Digital Literacy 21st Century Competences for Our Age The Building Blocks of Digital Literacy From Enhancement to Transformation. Green Paper: Digital Literacy. Available in https://education.go v.mt/en/elearning/Documents/ Green\%20Paper\%20Digital\%20Literacy\%20v6.pdf. (Accessed Date: Febru -ruary 18, 2017).

[11] Bawden, D., and Robinson, L., (2008). The Dark Side of Information: Oveload. Anxiety and Other Paradoxes and Pathologies. Journal of Information Science, XX (X), pp. $1-12$.

[12] DiMaggio, P., and Hargittai, E., (2001). From the 'Digital Divide' to 'Digital Inequality': Studying Internet Use as Penetration Increases. Working Paper Series, 15.

[13] Edward K., Owusu-Ansah., (2004). Information Literacy and Higher Education: Placing the Academic Library in the Center of a Comprehensive Solution. Journal of Academic Librarianship, Volume 30, No. 1, pp. 3-16.

[14] Eshet-Alkalai, Y., (2004). Digital literacy: a Conceptual Framework for Survival Skills in the Digital Era. Journal of Educational Multimedia and Hypermedia, Volume 13, No. 1, pp. 93-106.

[15] Fuaidah, T., (2013). Implementasi Pemanfaatan Media Blog Dalam Meningkatkan Kreativitas Mahasiswa Jurusan Pendidikan Agama Islam di IAIN Sunan Ampel Surabaya. Tesis Program Pasca sarjana IAIN Sunan Ampel Surabaya.
[16] Kuiper, E., Volman, M. \& Terwel, J. (2005). The Web as an Information Resource in K-12 Education: Strategies for Supporting Students in Searching and Processing Information. Review of Educational Research, 75(3), 285328. Retrieved January 11, 2019 from https://www.learntechlib.org/p/70113/.

[17] Li, Y., \& Ranieri, M. (2010). Are «Digital Natives» really digitally competent? A study on Chinese teenagers British Journal of Educational Technology, 41(6), 10291042.

[18] Spengler, S., (2015). Educator's Perception of a 21st Century Digital Literacy Framework. Walden University Scholar Works.https://scholarworks.waldenu.edu/cgi/ viewcontent.cgi?referer $=\&$ httpsredir $=1 \&$ article $=1555 \&$ con text=dissertations. (Access date: 13 March 2016).

[19] Ng, W., (2012). Can we teach digital natives digital literacy? Computers \& Education Journal, Volume 59, Issue 3, pp. 1065-1078.

[20] Prensky, M. (2001a). Digital natives digital immigrants part 2: Do they really think differently? On The Horizon, 9(6), 3 - 16. http://dx.doi.org/10.1108/10748120110424843

[21] Prensky, M. (2001b). Digital natives, digital immigrants part 1 . On The Horizon, 9(5), $3-6$. http://dx.doi.org/10.1108/10748120110424816.

[22] Van Deursen, A.J.A.M. \& Van Dijk, J.A.G.M. (2008) Measuring digital skills. Performance tests of operational, formal, information and strategic Internet skills among the Dutch population. Presented at the ICA Conference Montreal 22-26 May 2008.

[23] Van Deursen, A., and van Dijk, J., (2009) Improving digital skills for the use of online public information and services. Government Information Quarterly 26: 333-340.

[24] Leah, G., \& Panagiotis, M., (2003). Of course it's true; I saw it on the Internet! Commun. ACM. 46. 70-75. $10.1145 / 769800.769804$.

[25] Margaryan, A., Littlejohn, A., (2008) Are digital natives a myth or reality? Students' use of technologies for learning.http://citeseerx.ist.psu.edu/viewdoc/Download?do $\mathrm{i}=10.1 .1 .172 .7940 \& \mathrm{rep}=\mathrm{rep} 1 \&$ type $=$ pdf. (Access date: 12 November 2016).

[26] Livingstone, S., and Bober, M., (2005) UK Children Go Online: Final Project Report. London: LSE. URL (consulted Nov. 2008).

[27] Livingstone, S., and Helsper, E.J., (2007) 'Gradations in Digital Inclusion: Children, Young People and the Digital Divide', New Media and Society 9(4): 671-696.

[28] van Deursen, A. J. A. M., Helsper, E. J., \& Eynon, R. (2014). Measuring digital skills. From Digital Skills to Tangible Outcomes project report. Retrieved from www.oii.ox.ac.uk/research/projects/? id=112 